\title{
Theloscopic and Ultrasonographical Evaluation of Internal Teat Obstruction in Cows and its Treatment using Video assisted Theloscopic Electro resection
}

\author{
B. Udayakumari ${ }^{1 *}$, T. P. Balagopalan' ${ }^{2}$ N. Aruljothi' ${ }^{2}$ and B. Ramesh Kumar \\ Department of Veterinary Surgery and Radiology, \\ Rajiv Gandhi Institute of Veterinary Education and Research, Puducherry-605 009, India \\ *Corresponding author
}

Keywords

Theloscopy, ultrasonography, Electroresection

\section{Article Info}

Accepted:

15 February 2020

Available Online:

10 March 2020

\section{A B S T R A C T}

The present study was conducted in 18 cows, divided into three groups (I,II and III ) of six animals each based on the type of internal obstructive lesion viz; focal (Type I), diffuse (Type II) and membranous (Type III) respectively. The location and morphometry of the obstructive lesion was confirmed by ultrasonographical examination. Axial theloscopy of the teat was performed to visualize the nature, location and extent of lesion. Theloscopic electroresection was performed by cutting of the obstructive lesion at $70-80^{\circ} \mathrm{c}$ and coagulating at $80-90^{\circ} \mathrm{c}$ was performed and $50-90 \%$ of the mass could be resected from all the teats which was confirmed by ultrasonography. Intramammary infusion through the prosthetic tube kept insitu and systemic antibiotic were administered for 5 days. The procedure improved the milkability without any recurrence till $30^{\text {th }}$ day postoperatively.

\section{Introduction}

Covered teat lesions form the major etiological factor for milk flow disorder in cattle. The lack of knowledge about the pathophysiological process, non-availability of advanced diagnostic tools and equipments for treatment, failure in maintaining the patency of the lumen of the teat during postoperative period and the high cost of medicines are few hurdles still exixting in achieving $100 \%$ success rate in management of such condition in cattle. Ultrasonography is fast, accurate non-invasive means for investigation of structural alterations within the teat, assessing the location and nature of intraluminal obstructive lesions and postoperative evaluation of the teat (Szencziova and Strapak 2012). Theloscopy can be used for both diagnosis and monitoring of the surgical treatment. (Querengasser et al., 1999). It has been proved that theloscopy was 
a minimal invasive procedure proved to be a valuable imaging modality to investigate, document and categorize the diverse alterations of the inner teat cistern lining. It is atraumatic and free of major postoperative complications such as hemorrhages, inefficient wound healing and mastitis (Giehauser and Querengasser 2001). Videoassisted theloscopic electro resection is a promising, novel and minimally invasive technique for the surgical correction of internal obstructive lesions (Bleul et al., 2005). The present study is discussed on the theloscopical evaluation of the teats with internal lesions in cows under conventional milking system and evaluation of the theloscopic electroresection technique for management of internal teat obstructions in cows.

\section{Materials and Methods}

Eighteen cows presented with a history of milk flow disorders to the large animal surgical ward of the Teaching Veterinary Clinical campus, Rajiv Gandhi Institute of Veterinary Education and Research, diagnosed to have internal obstructive lesions in the teat cistern above the streak canal were selected for the present study. Following clinical examination of the teat cistern preoperatively, ultrasonographical examination was performed by B-mode diagnostic ultrasound scanner using 7.5 MHZ linear probe by water bath method (Rambabu et al., 2008) to confirm the location and morphometry of the obstructive lesion (Fig.1).

These animals were randomly divided into 3 groups of 6 animals each. Animals showing type I lesions (Focal teat obstruction <30\% mucosa ) were allotted to group I (IA - IF), type II lesions ( Diffused teat obstruction > $30 \%$ mucosa) to group II (IIA - IIF) and type III lesions ( Membranous lesion separating the gland and teat cistern ) to group III (IIIA-
IIIF) by ultrasonography. Milkability of the affected teat (Milk yield per quarter $(\mathrm{kg})$ and Milk flow rate per quarter $(\mathrm{kg} / \mathrm{min})$ and quality of milk (color, consistency and California mastitis test) was assessed preoperatively (Amitkumar et al., 2006). All the animals were prepared by withholding feed for 24 hours and water for 12 hours prior to theloscopy.

Theloscope instrumentation set (Fig.2 \& 3) was prepared aseptically. Theloscopic examination (Karl Storz) of the teat cistern was performed by axial approach under aseptic precautions. The procedure was performed under sedation with Inj.Xylazine (Xylaxin injection, Indian Immunologicals Ltd) @ $0.1 \mathrm{mg} / \mathrm{kg}$ body weight intravenously. The animals were kept on lateral recumbency with the affected teat placed above and the affected teats were prepared aseptically. (Fig.4). Local analgesia of the teat was achieved by ring block using 2\% Lignocaine hydrochloride solution (Tignocaine 2\%, Tamman Titoe Pharma Pvt. Ltd).A blunt trocar and canula of size was inserted into the teat cistern (Fig.5) upto the level of obstruction blindly through the streak canal in such a way to assess the type and extent of obstruction. The trocar was replaced by the theloscope sleeve (Fig.6) size of $1.9 \times 2.1 \mathrm{~mm}$ along with the wire snare and assessed the type and extent of the lesion.

Theloscopic examination of the obstructive lesion was performed under the constant flushing of $3 \%$ solution of glycine. The size, nature of the lesion and other pathological changes were evaluated and documented as described by Rathod et al., (2009).

The obstructive lesions were excised at its origin in the teat cistern by simultaneous cutting at the temperature of $\left(70-80^{\circ} \mathrm{c}\right)$ and coagulating at $80-90^{\circ} \mathrm{c}$ was performed using theloresectoscope (Fig.7). The quarter was 
flushed $0.9 \%$ normal saline to remove the blood clots/ tissue remnants and milk (Bleul et al., 2005).

The sterile prosthetic tube (Infant feeding tube No.9/10 - Romsons Scientific and Surgicals, India) was inserted into the teat sinus, fixed in situ with stay sutures (Fig.8) and protected using a sterile condom applied over the entire teat (Fig.9) (Aruljothi et al., 2009). Streptopenicillin was administered Intramammarily and IM daily for 5 consecutive days. The effectiveness of this procedure was assessed by evaluating milk ability, qualitative analysis of milk and ultrasonographical examination on $5^{\text {th }}$ and $30^{\text {th }}$ postoperatively.

\section{Results and Discussion}

Preoperatively, in group I, internal palpable lesions could be noticed at the base in 5 cows and at mid teat in $1 \mathrm{cow}$, in group II it was at the base in 4 cows and at mid teat in 2 cows and in group III, it was at the base in 5 cows and at mid teat in 1 cow. It may be due to the local tissue response to the irritation at the site of obstruction while milking or suckling. The teat cistern was found non-patent with the length ranged from 4.8 to $7.2 \mathrm{~cm}$ (group I), 3.2 to $8.6 \mathrm{~cm}$ (group II) and 5.0 to $7.2 \mathrm{~cm}$ (group III). Probing of the teat cistern was useful to detect the level of obstruction and the consistency of the obstructive lesion. The increased length noticed in group III may be due to the flexibility of membranous septum.

The milk yield and milk flow rate per quarter of the affected teat was found to be nil preoperatively which explains the outcome of the disease process.

Ultrasonographic images of the affected teats on preoperative day (Fig 10a-27a) in group I and II were showing non-patent teat cistern with hyperechoic proliferative mass extending towards the lumen obstructing the free flow of the milk in all the animals covering almost $20-30 \%$ and $70-90 \%$ of the lumen respectively. In case of group III, hyperechoic septum on the mucosal septum on the mucosal lining of the teat cistern, separating the teat and gland cistern obstructing the free flow of milk. The sizes of the mass in group I, II and III ranges from 7.6-9.3 x 3.4-11.6 mm, $14.6-19.7 \times 8.8-13.7 \mathrm{~mm}$ and $1.2-3.3 \times 5.8-$ $22.7 \mathrm{~mm}$ respectively.

There was diffused anechoic area indicative of dilated blood vessels in the teat wall in animal no.IB, IF, IIE, IIIA, IIIC and IIID and in the lesion in animal no.IIIE. There was irregular inflamed teat cistern mucosa in animal no. IC \& ID, presence of irregular folds of thickened mass in animal no.IIA and diffused hyperechoic teat wall in animal no.IIF preoperatively. The anechoic region in the teat wall, hyperechoic teat wall and irregular mucosal lining were indicative of inflammatory changes occurred in the teat tissues.

Theloscopical examination (Fig28a-45a) showed the presence of focal pinkish nodular proliferation in the teat cistern with inflammatory thickening of the mucosa in case of focal teat obstruction. In diffused teat obstruction, there were diffused whitish proliferative mass in the teat cistern with thickening of the mucosa. In membranous type of teat obstruction, pinkish septum from the mucosa of the teat cistern into the lumen separating the teat and gland cistern obstructed the patency with congested mucosa of the teat cistern. Once after the video assisted theloscopic electro resection of the lesion, milk flow was noticed and the patency of the teat cistern was confirmed by theloscopy (Fig 28b-45b) with 60-80\%, 60$90 \%$ and $60-80 \%$ in group I, II \& III respectively. Resection of the type III obstructive lesion at their origin has given good result than approaching through the 
centre portion. About 50-90\% of the obstructive lesion could be resected which was confirmed by ultrsonography on $5^{\text {th }}$ postoperative day. There was hemorrhage from the teat noticed following resection in 9 cows (IA, IE, IF, IIC, IID, IIIA, IIIC, IIIE \& IIIF) which was treated with Inj. Carbazochrome salicylate @ 25 mg and got controlled by $5^{\text {th }}$ day. The sterile prosthetic tube inserted into the teat cistern was useful for draining of milk, flushing the teat cistern and gland cistern and for maintaining the patency of the lumen postoperatively.

The tube was well tolerated by all the animals. Application of sterile condom over the entire teat was effective in maintaining the tube in situ and protecting the teat from postoperative contamination as reported by Arighi et al., (1987) and Aruljothi et al., (2009a). The tube was removed on $3^{\text {rd }}$ day in 6 cows (animal no. IA, IE, IF, IID, IIIC \& IIF) due to occlusion of the tube with blood clots. The owners were advised to follow full hand milking.

The theloresectoscope (Karl storz) employed in this study was found to be appropriate for examination of the internal lesions of teat and resection of lesions in crossbred cows and was in accordance with the observations by John et al., (1998). Anesthetic technique employed in the present study was found satisfactory for performing theloresectoscopy by axial method in all cows as suggested by Marongiu (2012).

Theloscopic examination of the teat cistern was performed by axial approach under aseptic precautions. It was found to be a simple and practical method to investigate, document and categorize the diverse alterations of the inner teat cistern lining as reported by Bleul et al., (2005). Filling of the teat cistern using 3\% solution of glycine improved the visibility of the site of obstruction. The scope facilitated visualization of exact condition of the mucosa, intensity/ grade and eventual duration of pathological lesions. It allowed safe and definite intervention for covered teat lesions with comparatively less risk and inconvenience to the animals than the conventional method for diagnosis, therapeutic and to monitor the treatment as in agreement with Rathod et al., (2009). Theloscopical examination confirmed the location and nature of the lesion as assessed by probing and the ultrasonographical evaluation in the entire affected teat.

Postoperatively, on $30^{\text {th }}$ day there were no internal palpable lesions could be palpated. In all the affected teats, the cistern was found patent on $30^{\text {th }}$ postoperative day in all the cows. Milk yield from the affected quarter increased to $14,39 \& 55 \%$ in group I and in group II it was increased to $25,38 \& 57 \%$. Whereas in group III, it was increased to 47 , 66 and reduced to $61 \%$ on $5^{\text {th }}, 15^{\text {th }}$ and $30^{\text {th }}$ day of surgery.

This indicated that the functional capacity of the affected teat was increased after surgery. It was in agreement with the observation made by Querengasser et al., (2002) by machine milking. Even though there was an improvement in these parameters, the milkability traits maintained at a lower level when compared with that of contralateral teat even after 30 days postoperatively.

The observations on milkability traits reflected the anatomical and functional characteristics of the affected quarter and the teat (Antalik and Strapak, 2010). The authors explained the disease process preoperatively and shown the effectiveness of theloresectoscopy in restoring the functional capacity of the teat as suggested by Querengässer et al., (2002), Weiss et al., (2004) and Condino et al., (2010). 


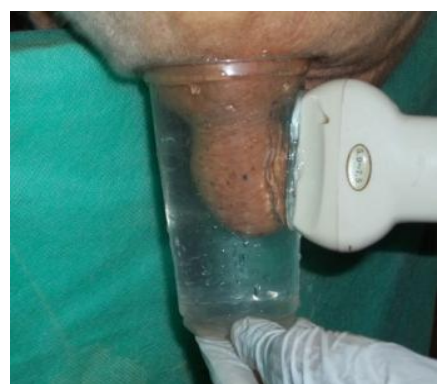

Fig.1 U/S by water bath method
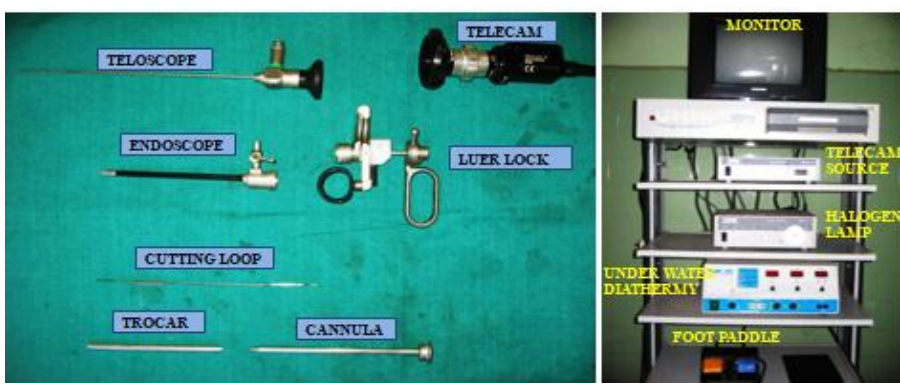

Fig.2\&3 Theloscope istrumentation set

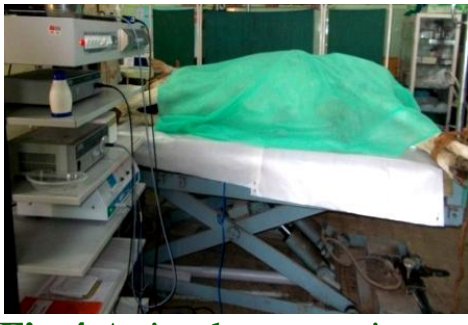

Fig.4 Animal preparation

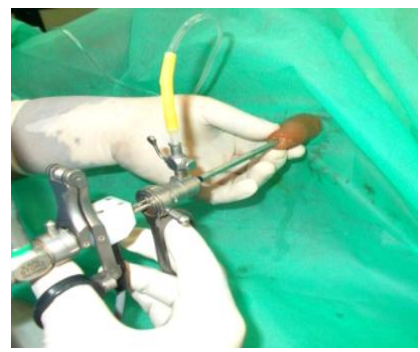

Fig.6 Theloscope inserted

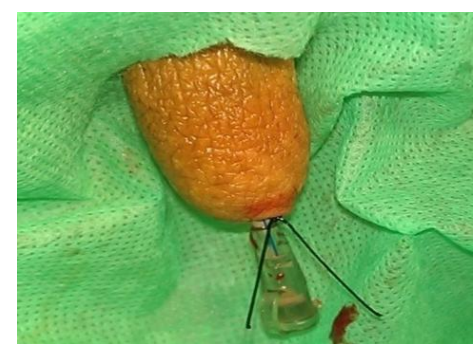

Fig.8 Prosthetic tube inserted and fixed insitu with stay sutures

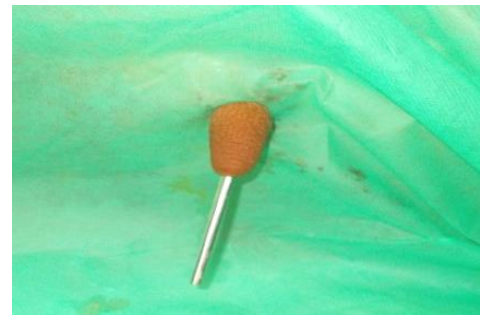

Fig.5 Cannula inserted into the teat cistern

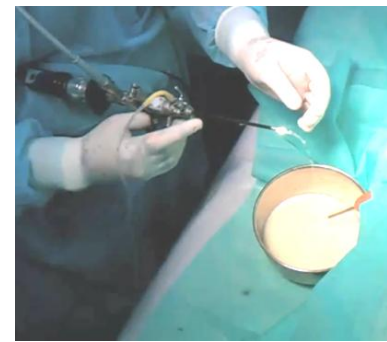

Fig.7 Video assisted theloscopic electro resection

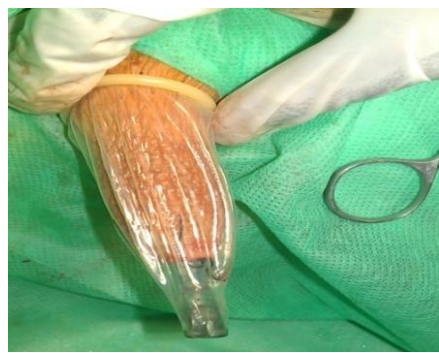

Fig.9 Sterile condom applied over the entire teat 

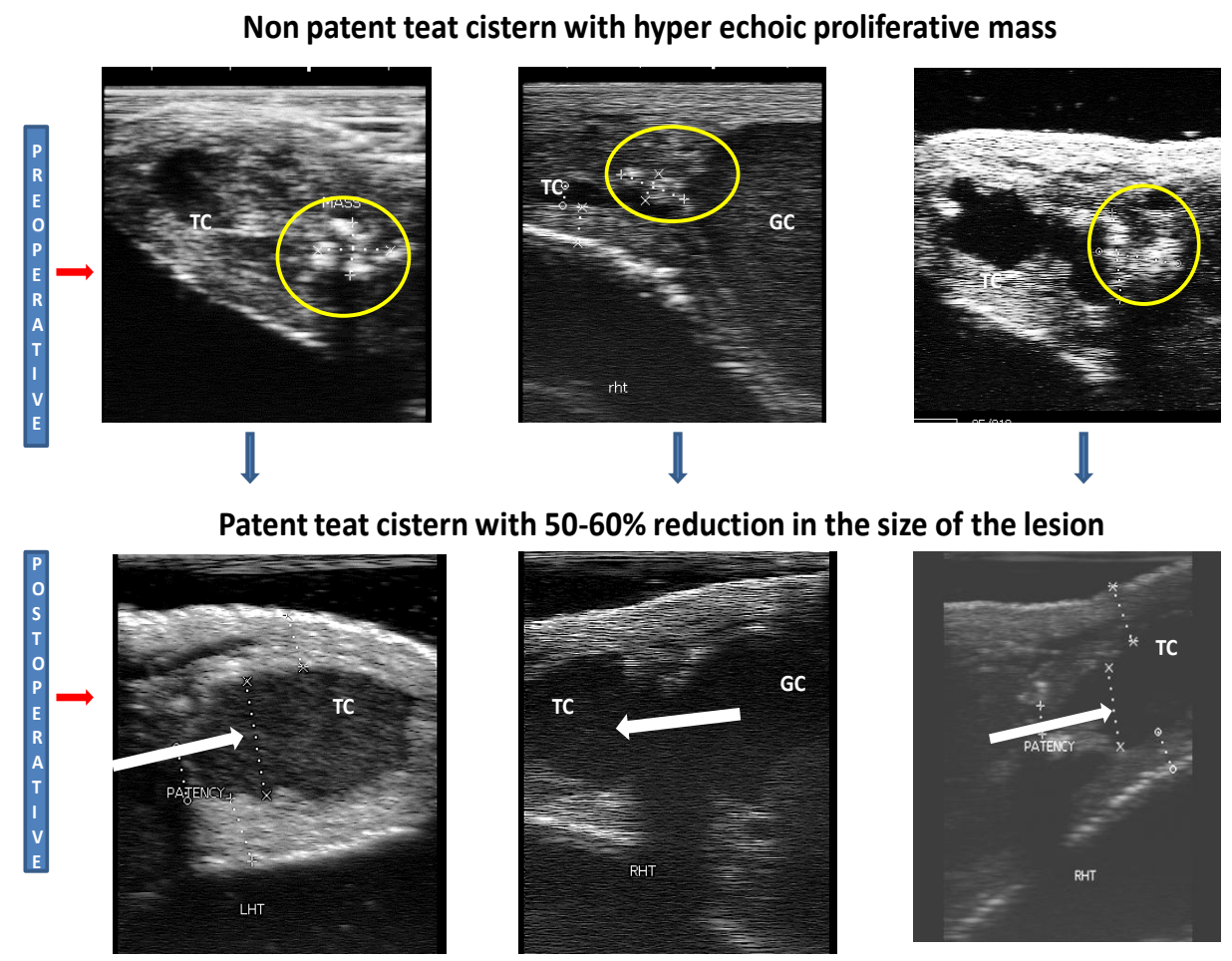

Non patent teat cistern with hyper echoic proliferative mass

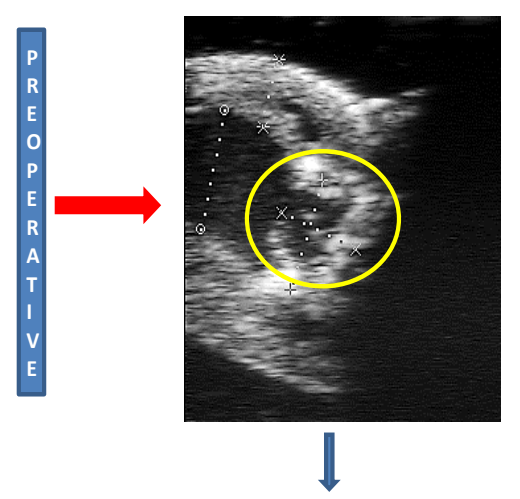

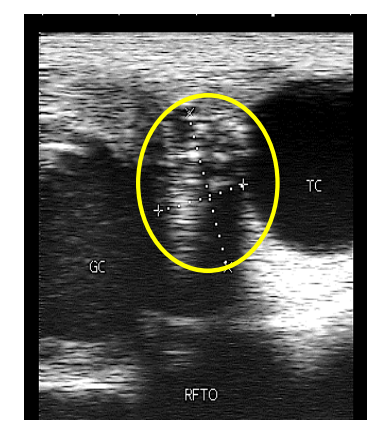

$\Downarrow$
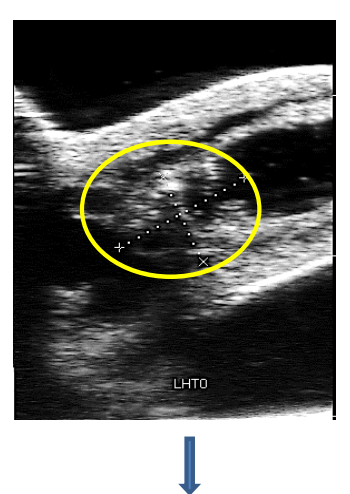

Patent teat cistern with $50-60 \%$ reduction in the size of the lesion, dilated blood

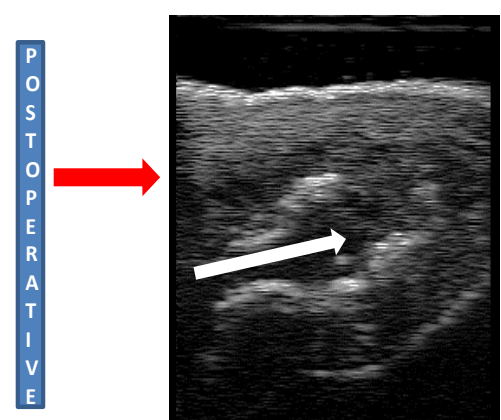
vessel in teat wall
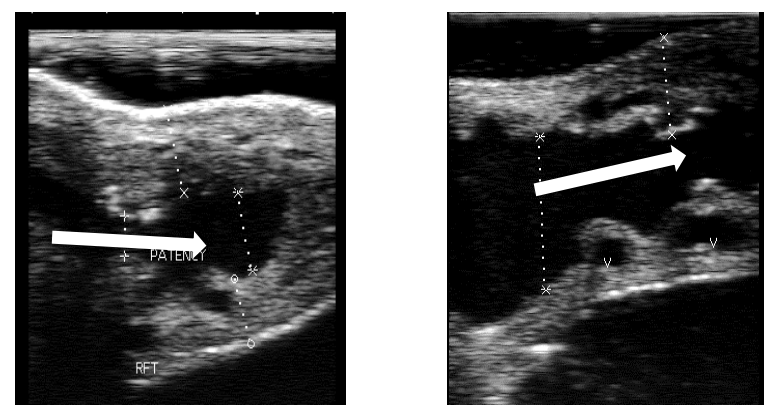

Ultrasonographic Images of the Affected Teat of Animals in Group I on Preoperative Day (10a-15a) and $5^{\text {th }}$ day Postoperatively (10b-15b)-(Ia-If) 
Non patent teat cistern with hyper echoic proliferative mass
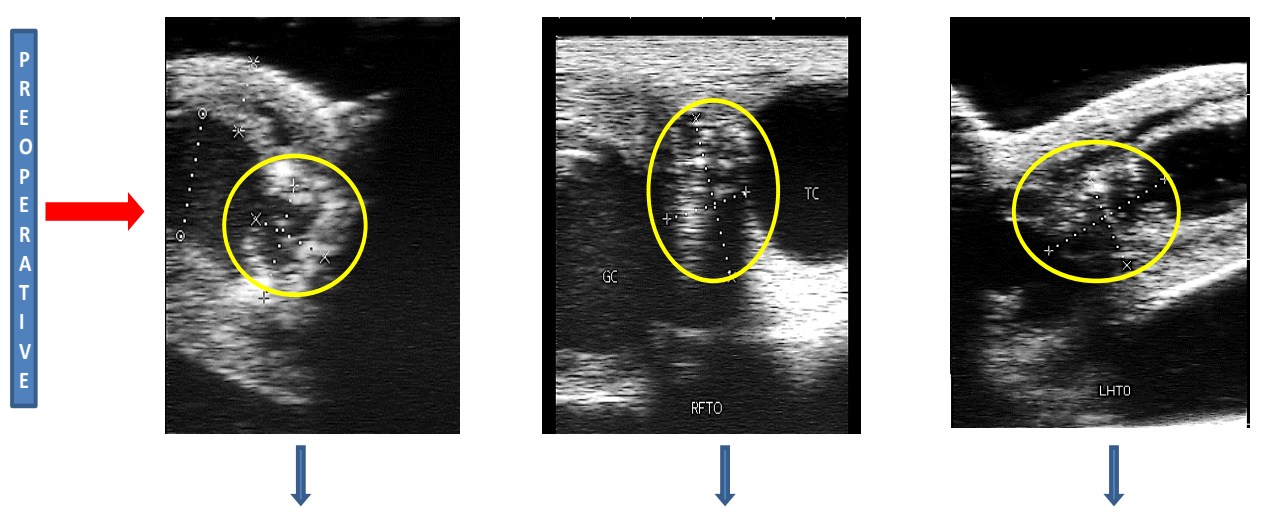

Patent teat cistern with $50-60 \%$ reduction in the size of the lesion, dilated blood

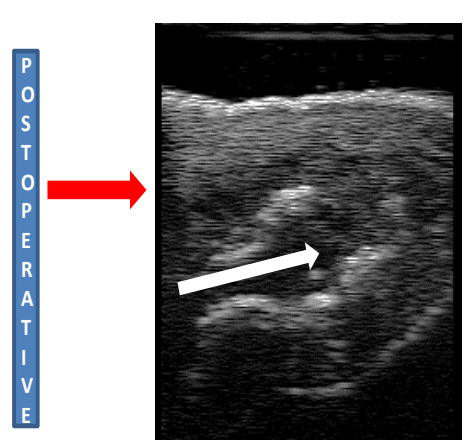
vessel in teat wall
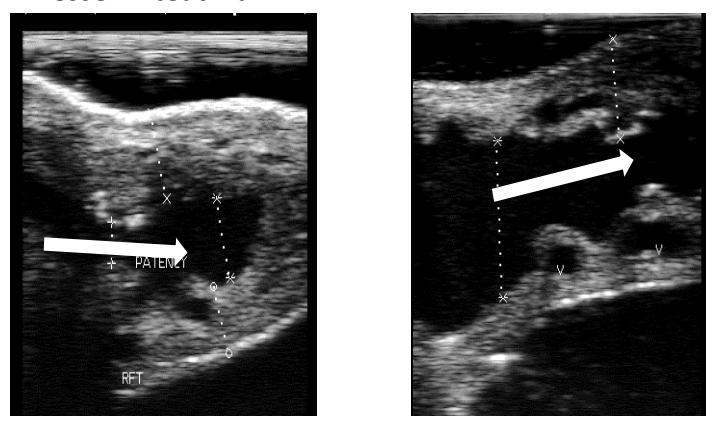

Non patent teat cistern with hyper echoic proliferative mass
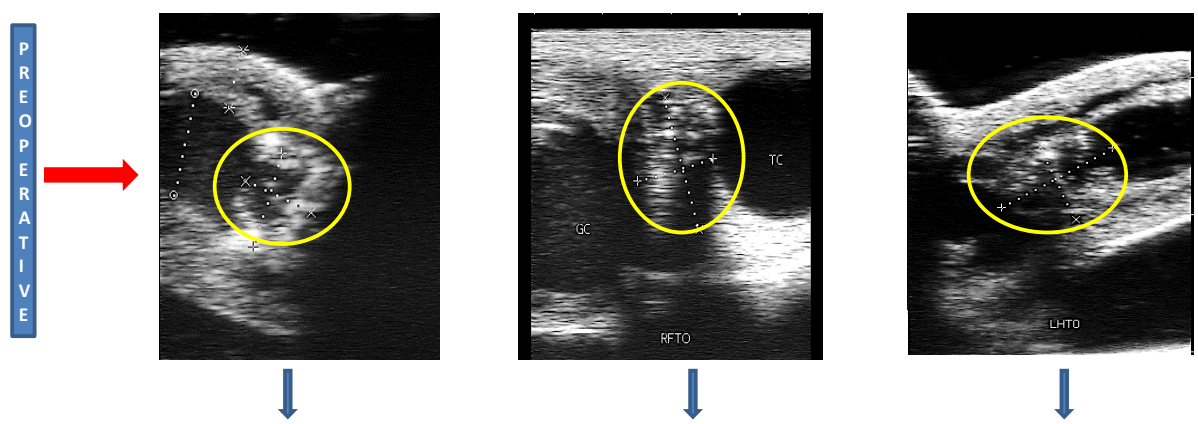

Patent teat cistern with $50-60 \%$ reduction in the size of the lesion, dilated blood
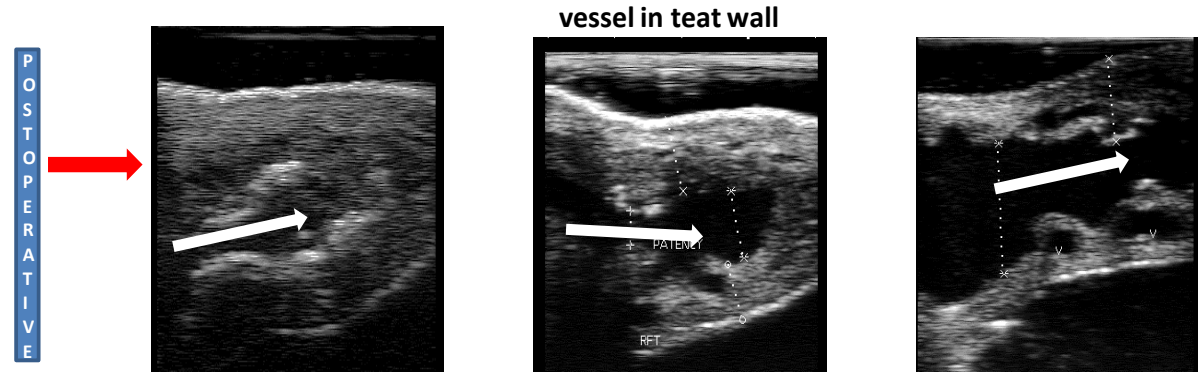

Ultrasonographic Images of the Affected Teat of Animals in Group Ii on Preoperative Day (16a-21a) and $5^{\text {th }}$ day Postoperatively (16b-21b)-(Iia-Iif) 


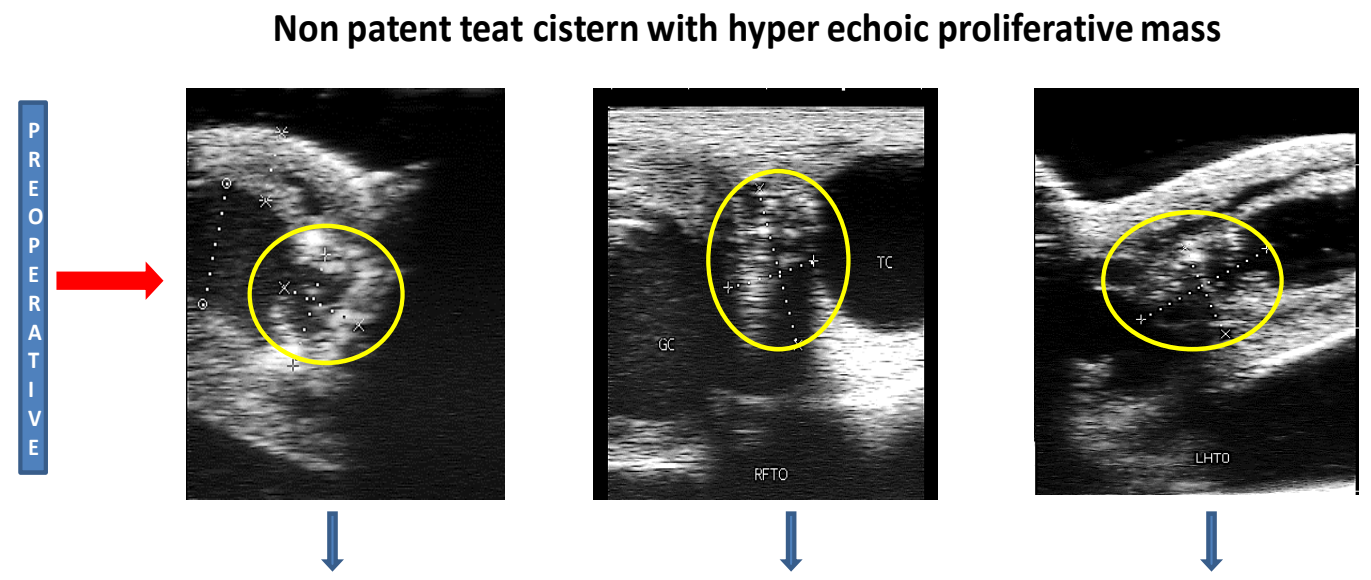

Patent teat cistern with $50-60 \%$ reduction in the size of the lesion, dilated blood

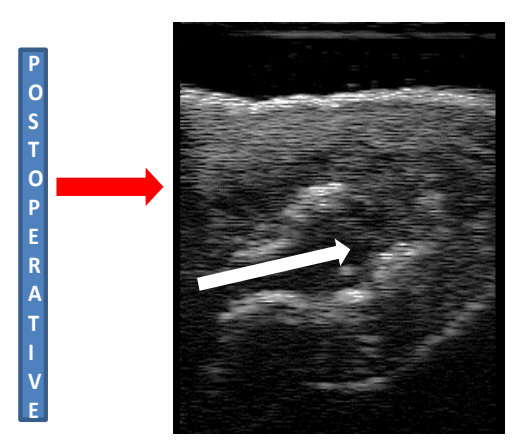
vessel in teat wall
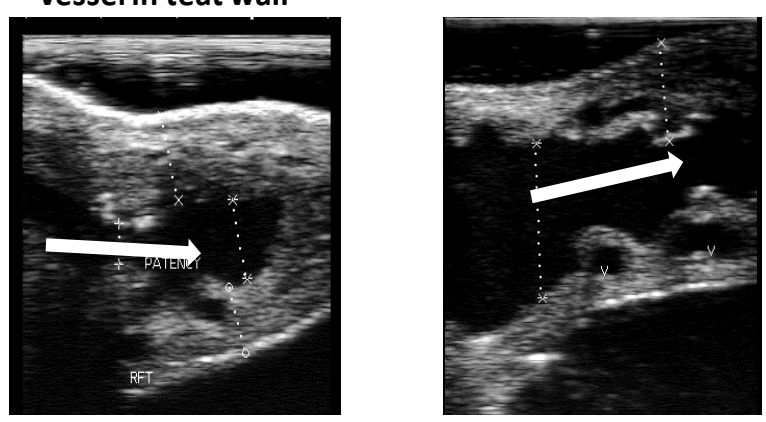

Non patent teat cistern with hyper echoic proliferative mass
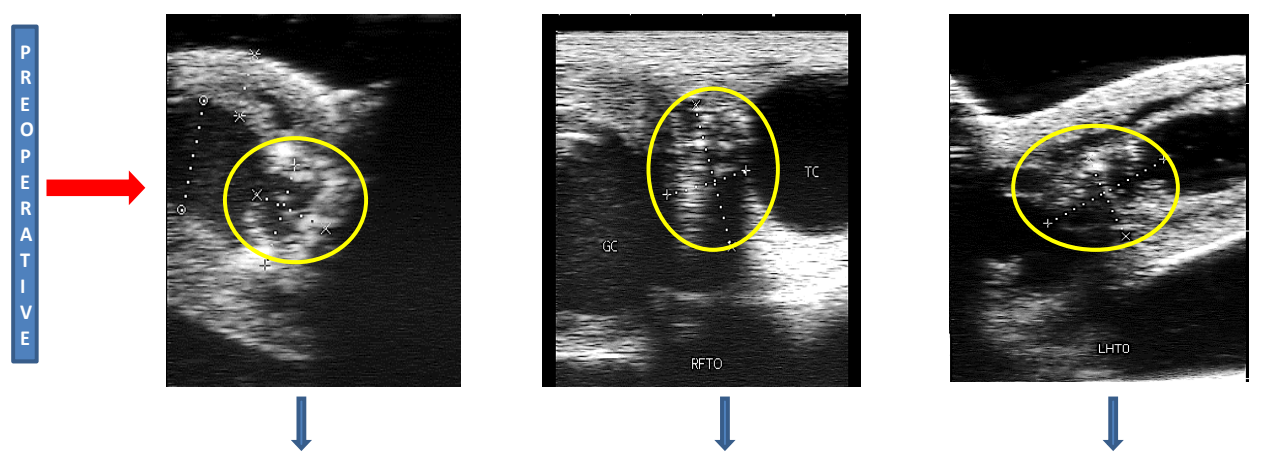

Patent teat cistern with $50-60 \%$ reduction in the size of the lesion, dilated blood

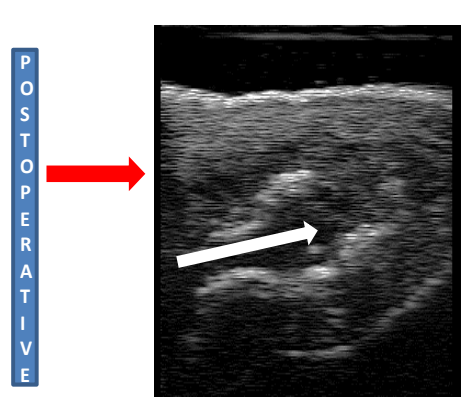
vessel in teat wall
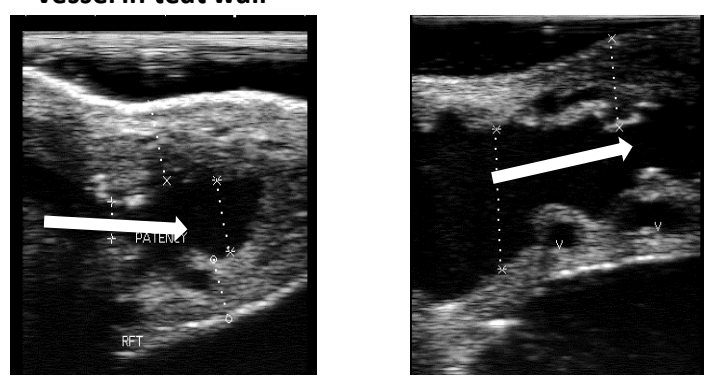

Ultrasonographic Images of the Affected Teat of Animals in Group Iii on Preoperative Day (21a-27a) and $5^{\text {th }}$ day Postoperatively (21b-27b)-(Iiia-Iiif) 
Focal pinkish thick folds in the middle of the cistern interspersed all over the cistern with irregular mucosal edges
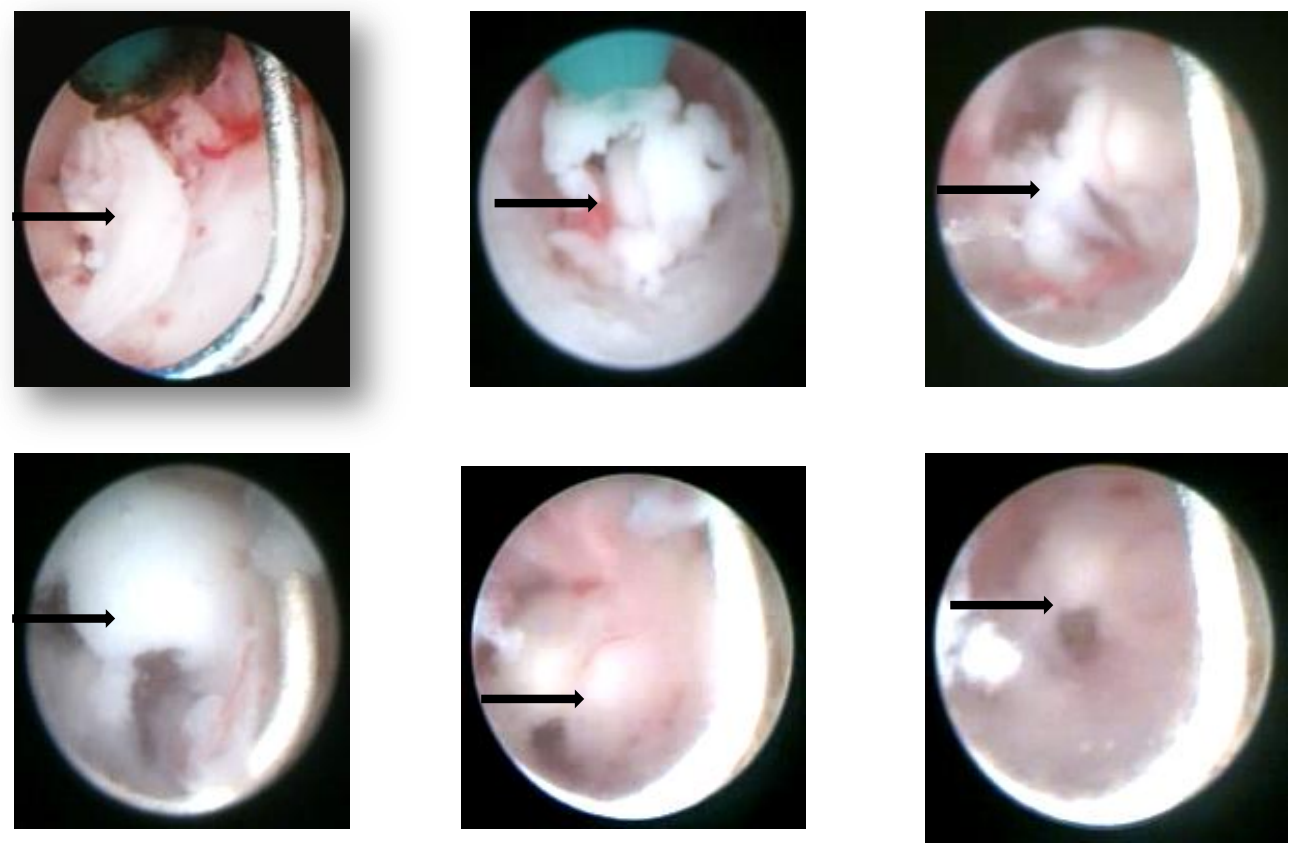

After electro resection

Improved patency of teat cistern with 60-80\% removal of the lesion
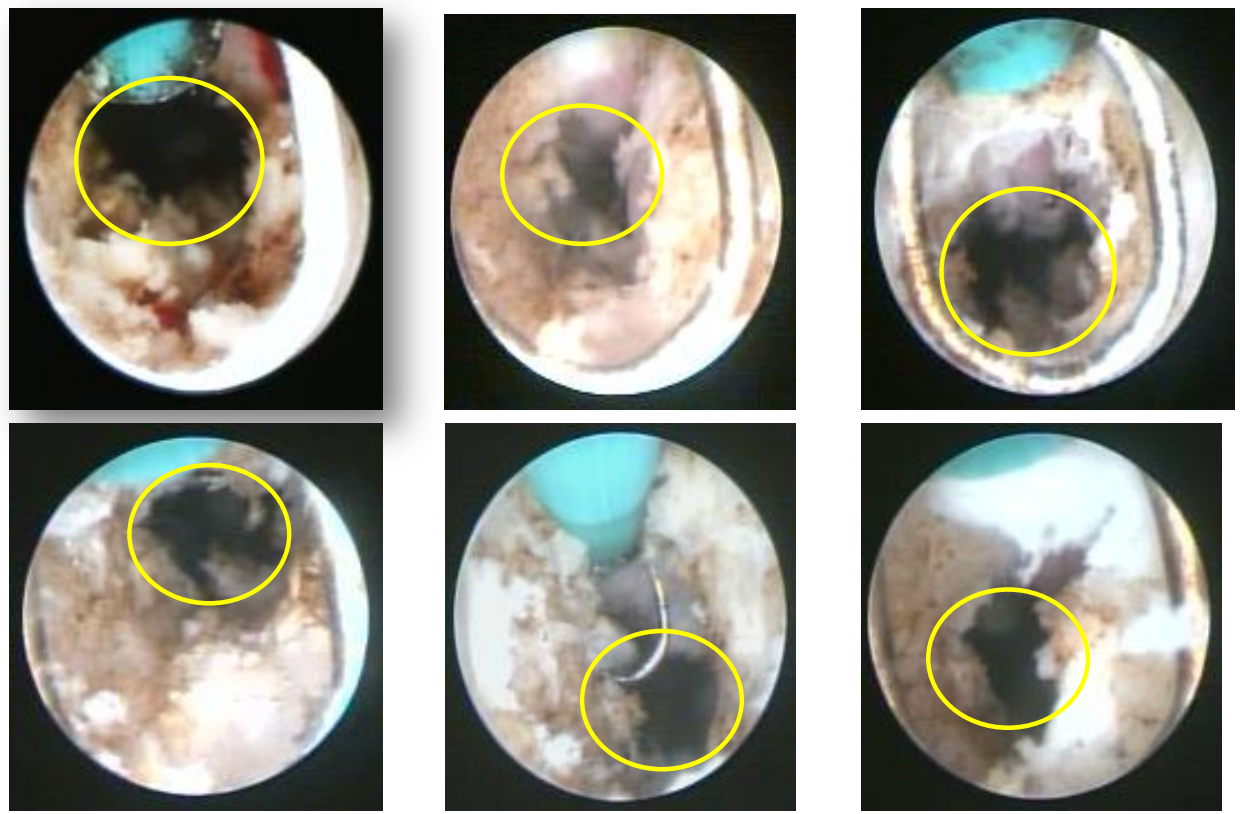

Theloscopic Images before (28a-33a) and after (28b-33b) Electro Resection of the Affected Teat in the Animals of Group-I with Type I Obstructive Lesion (Ia-If)-Focal Teat Obstruction 
Whitish diffused thick proliferative mass interspersed all over the cistern with thickening of the mucosa
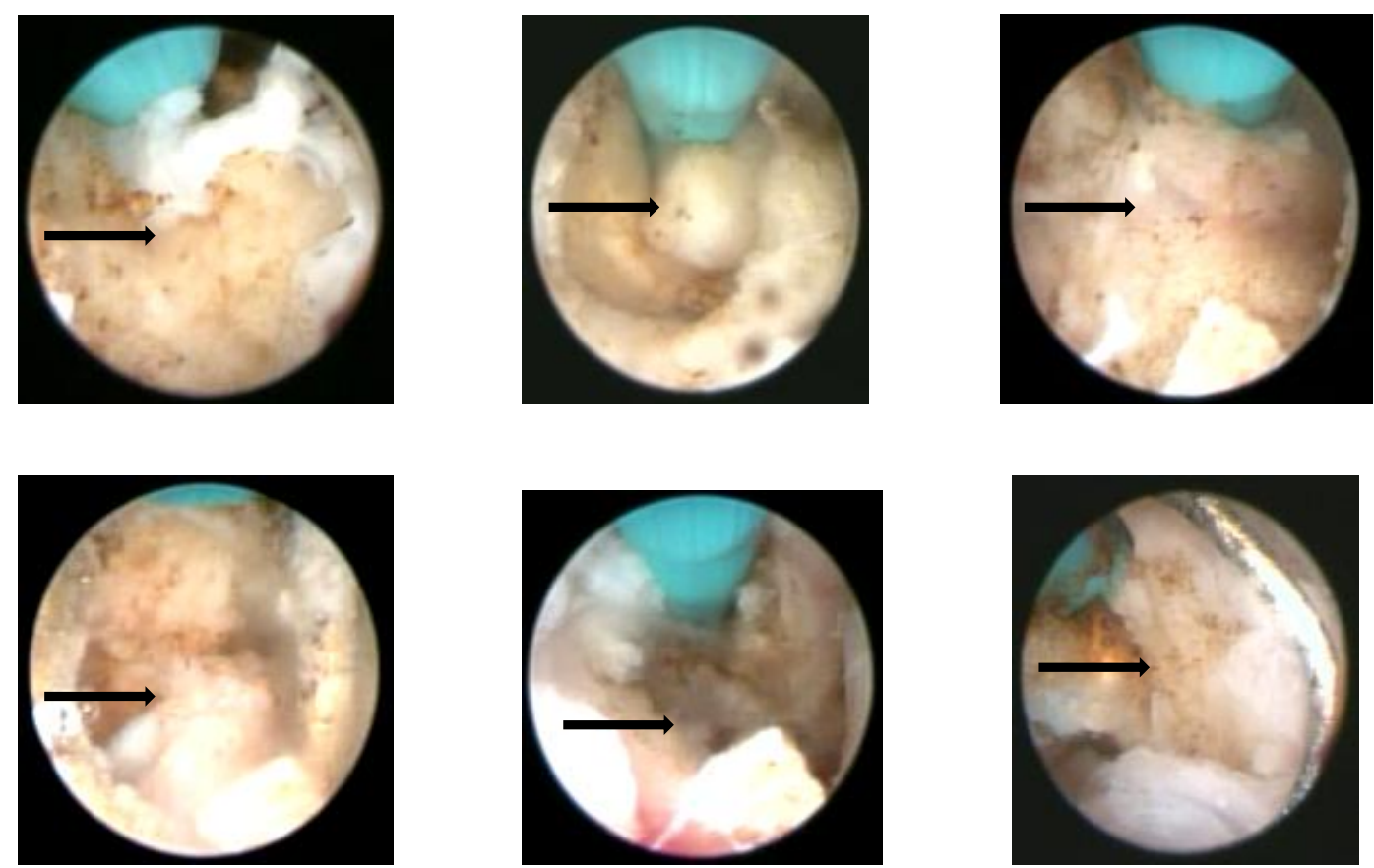

After electro resection

Improved patency of teat cistern with $60-90 \%$ removal of the lesion
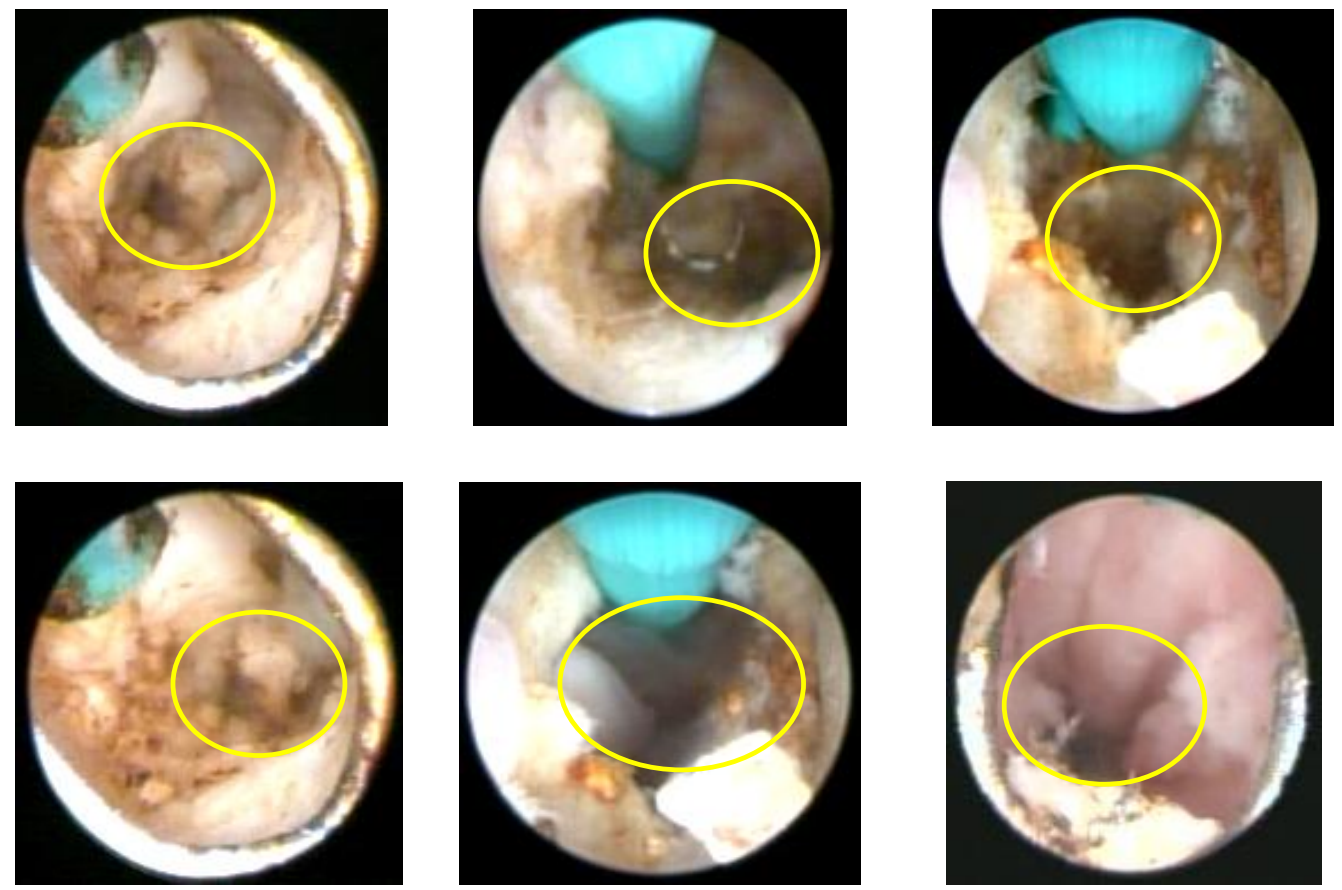

Theloscopic Images before (34a-39a) and after (34b-39b) Electro Resection of the Affected Teat in the Animals of Group Ii with Type Ii Obstructive Lesion (Iia-Iif)- Diffused Teat Obstruction 
Pinkish septum from the mucosa of teat cistern into the lumen at the base separating the teat and gland cistern obstructed the patency, with congested mucosa of the teat cistern
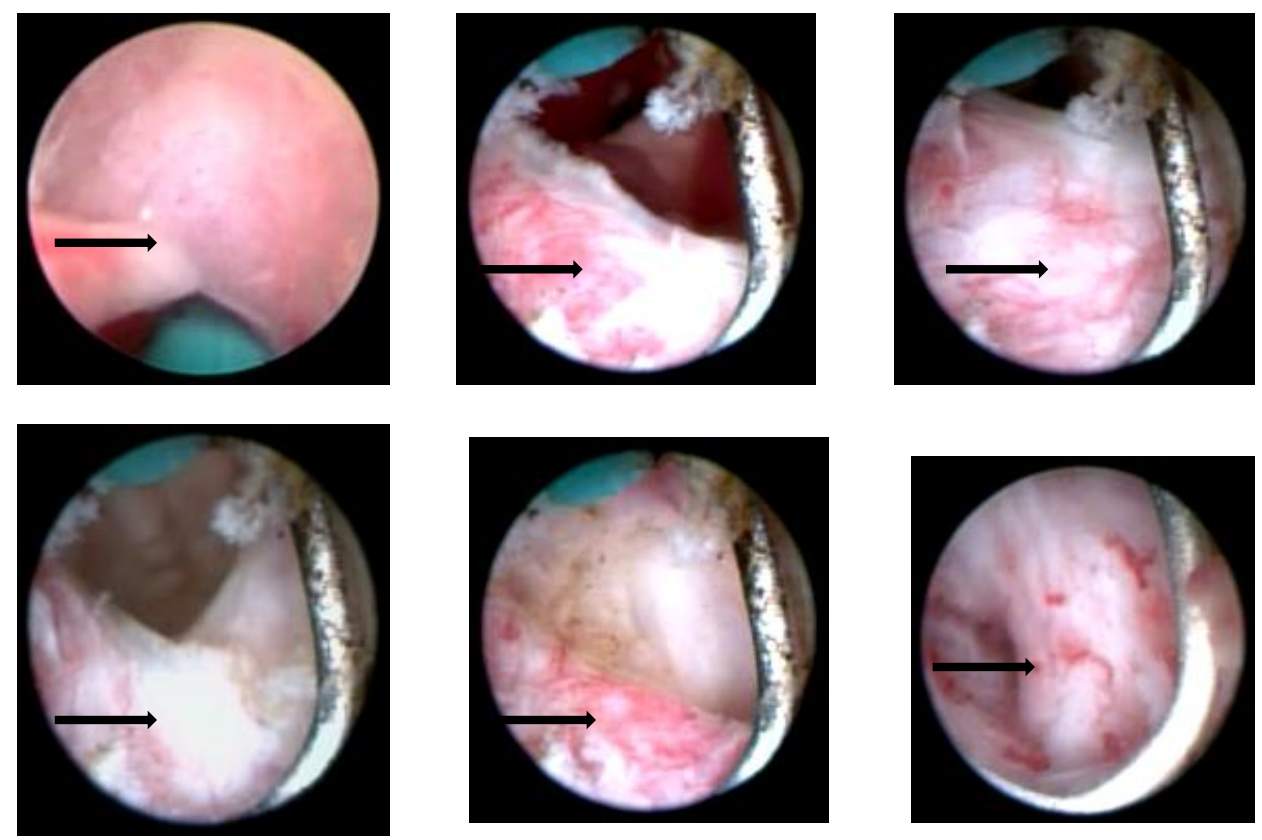

After electro resection

Improved patency of teat cistern with $60-80 \%$ removal of the lesion
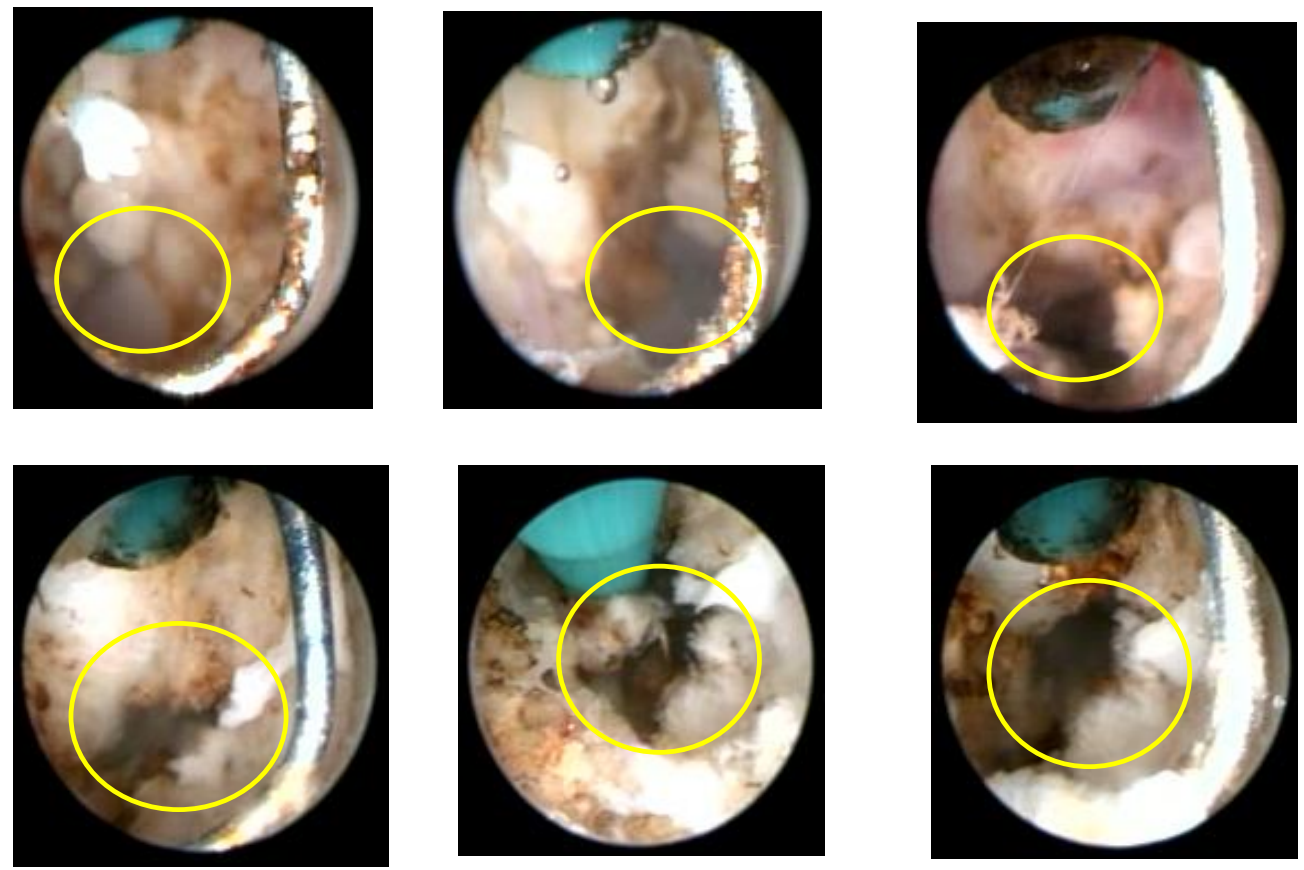

Theloscopic Images before (40a-45a) and after (40b-45b) Electro Resection of the Affected Teat in the Animals of Group Iii with Type Iii Obstructive Lesion (Iiia-Iiif)Membranous Teat Obstruction 
On $30^{\text {th }}$ postoperative day, the color and consistency of the milk from the affected teat was found apparently normal and showed negative for California mastitis test in all cows. Ultrasonographic images of the affected teat (Fig 10b-27b) on $5^{\text {th }}$ postoperative day were showing 50-60\%, 60$90 \%$ and $50-70 \%$ reduction in the size of the obstructive lesion in group I, II \& III respectively. There was reduction in the size of the internal lesion approximately to an extent of 50-90\% improving the patency of the teat cistern.

Ultrasonographical examination of the affected teat and that of the normal contralateral teat was performed preoperatively and on $5^{\text {th }}$ day postoperatively using water bath method. The use of the water bath for scanning of the mammary gland was increased the acoustic impedance difference between the teat wall and the surrounding medium (Cartee et al., 1986) and allowed visualization of all the teat structures except at the base of the teat which was in accordance with Rambabu et al., (2008) and Aruljothi et $a l$. , (2013). The teats, which were completely obstructed by the internal lesion, were filled with milk proximal to the obstruction. Distal to the obstruction the teat appeared to be collapsed. To further delineate the thickness, structure and extent of the obstruction, Normal saline was infused by retrograde method into the teat canal. Linear probe of 7.5 $\mathrm{MHz}$ was satisfactory for evaluating the pathological changes in the teat as reported by Gleeson et al., (2004) and Santos et al., (2004). The short term complication like hemorrhage noticed in 9 operated teats which became normal by $5^{\text {th }}$ postoperative day. There was no recurrence of the milk flow disorder in any of the animal treated by electro resection till $30^{\text {th }}$ postoperative day. None of the 18 cows that had undergone the surgery developed or was treated for mastitis during the period of observation. Theloscopic electro resection was a minimally invasive treatment modality for management of covered teat lesions in cows which can be performed by a single person and aided in restoring the anatomical and functional capacity, milk ability and quality of milk within a short period of time with minimum complications. It allowed safe and definite intervention for covered teat lesions with comparatively less risk and inconvenience to the animals than the conventional method for diagnosis, therapeutic and to monitor the treatment.

\section{References}

Amitkumar., Singh, R., Kant, N., and Kumar, y., 2006. Studies on factors affecting milk flow rate in buffaloes under farmer's conditions. J. Dairying Foods \& HS., 25: 59- 62.

Antalik, P., and Strapak, P., 2010. The evaluation of milkability of slovak pinzgau cattle by lactocorder. Slovak J.Anim.Sci., 43: 173-178.

Arighi, M., Ducharme, N.G., Horney, F.D., Livesey, M.A., and Hurtig, M.H., 1987. Invasive Teat Surgery in Dairy Cattle: II - Long-term Follow-up and complications. Can. Vet. J., 28: 763767.

Aruljothi, N., Balagopalan,T.P., Alphonse, R.M.D., Rameshkumar, B., and Kumar, R. (2009). A Clinical study on the use of prosthetic tubes for treatment of teat obstruction in cows. Indian J. Vet. Surg., 30: 47-48.

Aruljothi, N., Balagopalan, T.P., Rameshkumar, B., and Kantharaj, S., 2013. Use of Therapeutic Ultrasound for Management of Partial Obstruction of Teat in Cows. Indian Vet. J., 90: 91-93.

Bleul, U.T., Schwantag, S.C., Bachofner, C., Hässig, M.R., and Kähn, W.K., 2005. Milk flow and udder health in cows 
after treatment of covered teat injuries via theloresectoscopy: 52 cases (2000-2002). J. Am. Vet. Med. Assoc., 226: 1119-1123.

Cartee,R.E., Jgeahim,A.K., and McLeary,D., 1986. B-mode ultrasonography of udder and teat.J.Amer.Vet.Med.Assn., $\quad 188$ : 1284-1287.

Condino, M.P., Suzuki, K., Sato, K., Hyakutake, K., and Taguchi, K., 2010. Evaluation of a milk-flow assessment technique in dairy cows with normal teat canals or stenotic teat canals. Am. J. Vet. Res., 71:1123-1126.

Geishauser,T., and Querengässer, K., 2001. Using teat endoscopy (Theloscopy) to diagnose and treat milk flow disorders in cows. Bovine Pract., 35:156.

Gleeson, D.E., O’Callaghan, E.J., and Rath, M.V., 2004. Effect of liner design, pulsator setting, and vacuum level on bovine teat tissue changes and milking characteristics as measured by ultrasonography. Irish Vet. J., 57: 289296.

John, H., Hässig, M., Gobet, D., Sicher, D., and Jaeger, P., 1998. A new operative method to treat high teat stenoses in dairy cows. Br. J. Urol., 82: 906-909.

Marongiu, M.L., 2012. Local Anesthesia for Husbandry Procedures and Experimental Purposes in Farm Animals In "A Bird's-Eye View of Veterinary Medicine", Dr. Carlos C.Perez-

Marin(Ed.)http://www.intechopen.com/ books/a-bird's-eye view of veterinary medicine/local-anesthesia-for- husbandry-procedures-andexperimental- purposes-in-farmanimals.

Querengasser, K., Geishauser, T., and Hoptner, C., 1999. Effect of teat dilators and teat cannulas on udder health. Bov. Pract., 33: 130-135.

Querengässer, J., Geishauser, T., Querengässer, K., Bruckmaier, R., and Fehlings, K., 2002. Investigations on milk flow and milk yield from teats with milk flow disorders.J. Dairy Sci., 85: 810-817.

Rambabu, K., MakkenaSreenu., SureshKumar, R.V., and Rao, T.S.C., 2008. Ultrasonography of the udder and teat in buffaloes: a comparision of four methods.Buffalo B., 27: 269-273.

Rathod, S.U., Khodwe, P.M., Raibole, R.D., and Vyavahare, S.H., 2009. Theloscopy - the advancement in teat surgery and diagnosis. Vet. World., 2: 34-37.

Santos, D., Vicente, W., Canola, J., and Lega, E., 2004. B- mode ultrasonography in cows during lactation to evaluate the teat anatomy using four different techniques. Braz.J.Vet.Anim. Sci., 41: 349-354.

Szencziova, I., and Strapak, P., 2012. Ultrasonography of the udder in cattle:A perspective measuring technique. Slovak.J.Anim.sci., 45: 96-104.

Weiss, D., Weinfurtner, M., and Bruckmaier, R.M., 2004. Teat anatomy and its relationship with quarter and udder milk flow characteristics in dairy cows. $J$. Dairy Sci., 87: 3280-3289.

\section{How to cite this article:}

Udayakumari. B., T. P. Balagopalan, N. Aruljothi and Ramesh Kumar. B. 2020. Theloscopic and Ultrasonographical Evaluation of Internal Teat Obstruction in Cows and its Treatment using Video assisted Theloscopic Electroresection. Int.J.Curr.Microbiol.App.Sci. 9(03): 20572069.doi: https://doi.org/10.20546/ijcmas.2020.903.236 